\title{
The Place and the Role of the Intellectual Property Assets in the Knowledge Based Organization Context
}

\author{
Mihail Aurel ȚîȚU \\ „Lucian Blaga” University of Sibiu, Sibiu, Romania \\ mihail.titu@ulbsibiu.ro \\ Constantin OPREAN \\ „Lucian Blaga” University of Sibiu, Sibiu, Romania \\ constantin.oprean@ulbsibiu.ro \\ Ștefan ȚîȚU
}

„Iuliu Haţieganu” University of Medicine and Pharmacy, Cluj Napoca,Romania

stefan.titu@ymail.com

Andreea Simina RĂULEA

„Lucian Blaga” University of Sibiu, Sibiu, Romania

andreea.raulea@ulbsibiu.ro

Sebastian STAN

„Lucian Blaga” University of Sibiu, Sibiu, Romania

sebastian.stan@ulbsibiu.ro

\begin{abstract}
In the nowadays society, when the access to data and information is made easier to accomplish grace to the development of the information and telecommunication technologies, the issue to discuss is the use of knowledge with the purpose of creating the competitive advantage by producing knowledge. For the accomplishment of this purpose the actual situation has been analyzed to the level of European Union in what concerns the manner of valuing the intellectual property assets. The analysis revealed a model realized in the framework of a European research project. The conclusions of this scientific measure are pointed towards the optimism of the fact that, in time, each organization, no matter the size, the field of activity or the structure will be conscious of the assets that it owns and the way that they can be valued.
\end{abstract}

Keywords: intellectual property assets, knowledge based organization, the capitalization of the intangible assets. 


\section{GENERAL CONSIDERATION INTELLECTUAL PROPERTY ASSETS}

The historical moment where we are found is one where no matter the place in the world we are, we are able to access a large amount of information that no human being or a group of people would be capable of processing and remember. But just the information is not enough. For example, to be able to access the data disposed by the internet, a connection to the internet is not enough, it must be known the way of using the computer, what means owning some knowledge. The characteristic of the knowledge based society is not that we have great amount of information but that in this framework we must find out more through the process of their transformation in knowledge (new products, technology, etc).

The contemporary economic landscape is shaped not only by physical waves of goods and material products, but also by intangible values and waves of data, images, and symbols. This situation develops the conditions for making a change in the organizations", complexity order. Because perceiving the organizations out of the economy and out of the relationship between them is absurd, it seems that in fact we assist to the apparition of a new type of organization: knowledge based organization.

In the new economic reality, the change of knowledge at the tactic or strategic level, together with the change of intangible values and benefits become the main source of values creation. The change currency is not represented only by the money, but also by the knowledge or other intangible values such as the prestige or the loyalty of the clients. In such an environment, the old models used to describe the bookkeeping system, the organization and the economy can't capture the nowadays reality. This is the reason that leads to a new manner for reporting to the intellectual property assets that represent the competitive advantage which most of the organizations don't take knowledge of and even less values it.

The passage to the knowledge based economy, to the construction and functioning of the knowledge based organizations, it can't be accomplished without a knowledge based management (Oprean, 2011). To the organization level, the knowledge is found to the human capital level, in the requests and preferences of the clients, more specific the clients capital, in the products, processes, its capabilities and systems that builds the structural capital. As a result, the value of the knowledge assets can increase in great number the value of intangible assets.

The intellectual property assets and their value most of the times are not adequately appreciated. But in the knowledge based organizations, the intangible goods represent the major interest point when decisions are needed to be made. What must be taken into consideration by the organizations, generally speaking, is the speed by which the new products, brands, models and the results of creativity come out on the market as a result of innovation and of the daily process of creation, rightfully appreciated. 


\section{RESEARCH REGARDING THE IDENTIFICATION OF NEW VISUALIZATION METHODOLOGIES AND EVALUATION OF THE INTANGIBLE ASSETS STATUS QUO IN EU}

The European capital market experts are found in the first line in what concerns the global developments. In 2008 the European Federation of Financial Analysts Societies- EFFAS, published "The principles for an Efficient Communication of the Intellectual Capital, establishing an European standard in what concerns the recommendations for the bookkeeping principles of valuation and presentation of information for the corporative intellectual assets (South East Europe Transnational Cooperation Programme, Application Form, Document Reg. No.: INTRA - 5182931- Documentation European Research Project EVLIA, 2012). According to EFFAS (European Federation of Financial Analysts Societies), intangible goods are defined as a category of goods in the context of financial markets, and also in the corporative bookkeeping and reputation, classifying the intangible goods as follows: the competences of the employees and of the management, the human capital, software, the research-development, innovation and capacity of innovation, brands and licenses, strategies, processes, relationships with the suppliers and with clients.

Taking into consideration the fact that most of the patent transactions are realized based on some non-disclosure contracts is difficult to tell the size and the evolution of the patent's markets. But, analyzing the reports and the statistics available, we can conclude that the paten's markets are on an increasing. The patent's market represents a significant step of innovation because it facilitates the spreading of technologies and ideas by the actions of encouraging the circulation of patents between a great numbers of organizations.

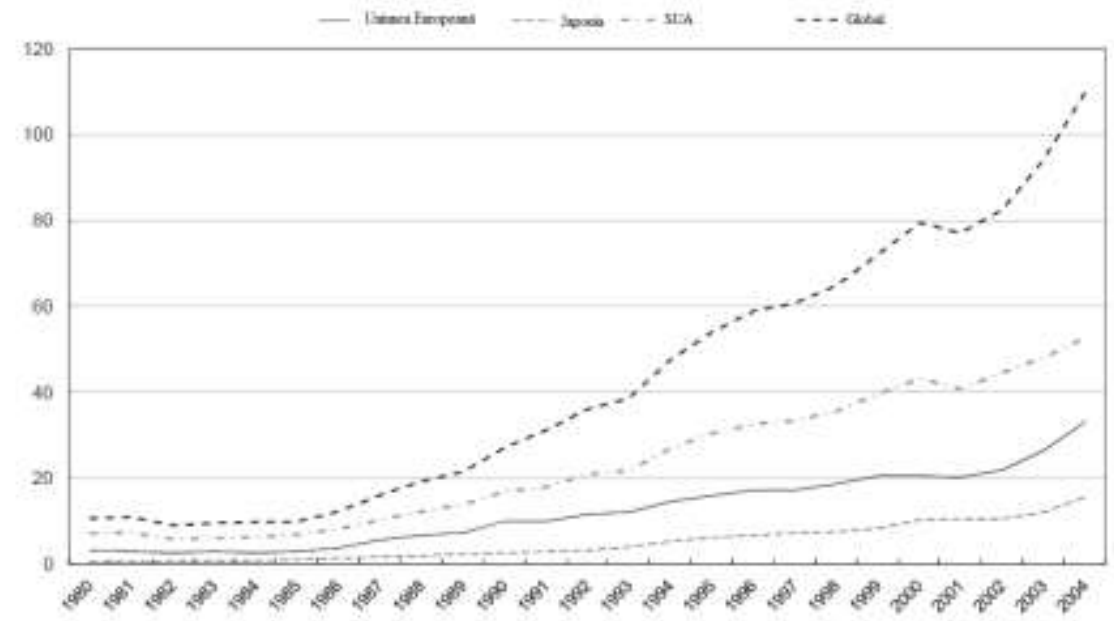

\section{Figure 1: Encashment from the international licensing (billions of dollars). Source: WIPO.}

The international licensing, for example, seems to be in a rising trend. The international encashment from intellectual property increased from 10 billion dollars in 2004, with more 
than $90 \%$ from the encashment for the three great areas: European Union, Japan and the United States.

Because of the apparition of new players whose business models are focused on the extraction of value from the intellectual property, the market of intellectual property has known significant changes. The way of action of the organizations that try to value the intangible goods that they own can be divided in various categories. On one hand the organizations try to value the patents by creating strategic portfolios of patents that they specialize. On the other hand, the organizations offer websites with the purpose of creating online markets where patents and ideas can be changed, and other organizations make cooperative structures that buy and license patents for their members in defensive purposes.

It is important to take into consideration that the intellectual property markets are rapidly developing by the apparition of new types of intellectual property transactions and new ways of development and supplement of intellectual property, which on their turn create new business models. This is the reason for which these must be carefully analyzed, for the purpose of creating transactions that may influence in a significant way the circulation of the patents and there can be created a favorable environment for the development of the knowledge based economy.

The way of action of these new players on the transactional markets for the patents and the evaluation approaches of the intellectual property used, are of a significant importance in the development of a framework for the valuation of the methodological set of tools which have a contribution to the making of a unique European market for the intellectual property.

Taking into consideration the fact that the intellectual property represents an important mean in the processes of innovation and a part in the intangible goods portfolio of an organization, we have the tendency to believe that is evaluated and treated equally with the tangible assets but, unfortunately, it hasn't been enough valued and treated as a true asset in the bookkeeping by the experts of the financial market. The lack of an evaluation approach being generally standardized is the weak spot of the knowledge based economy.

Nowadays, investment experts combine traditional methods, as the approach based on income, the approach by market comparison or the approached by costs with additional information taken of the market, according to specific conditions.

In certain countries, for example Austria and China, they are in process to establish the standardized evaluation methods which include a qualitative and a quantitative approach. In Italy, in 2008 a methodological approach was established based on the agreement between the Economic Development Minister, Banks association, Industrial Association, And University Association. Also, in Hungary, new evaluation approaches are explored at the national level. The European unitary patent gives a new leafing point adequate for introducing the intellectual property as an asset, regarding its valuation and evaluation 
from accounting point of view. The current European patent system is complex, fragmentary and expensive.

In 2011, the European Commission begun to explore the options for establishing an evaluation instrument of the rights for the intellectual property to the European level. In this context "the valuation" refers to the valuation of the intangible assets in terms of bookkeeping and to an increase in the number of the opportunities for obtaining a better value from the rights of intellectual property and to find financing. The valuation and exploit are two concepts inter-conditioned, in this context, the need for an improved evaluation is strongly tied to the expansion of the use of intellectual property. The necessity of financial evaluations of the intellectual property becomes relevant especially when they are used as financial tools by the organizations and as investment goods by the financial institutions and risqué capitalists.

For many organizations the professional management of the intellectual property is of an important critique. In fact, the intellectual property is the main good which determines value of an organization found at the beginning of its journey, and the decisions of investment are taken. (Manus, 2012). The intellectual property can be considered a key element in establishing the value of an organization. The basis evaluation methods are very much alike, fact that reduces in complexity and helps in determining the management key problems. The introduction of a national evaluation instrument or a standard of patents in the member states of the European Union must take into consideration the situation at a national level in what concerns innovation sector activity. Meanwhile the evaluation of patents or other forms of rights for the intellectual property and intangible goods present differences between the economic sectors, and these economic sectors are characterized by differences to the level of the use for the patents, the tools of evaluation must be adjusted to the level of countries regarding the activity that implies the rights for the intellectual activity and intangible goods.

\section{VALUE MODEL FOR THE INTANGIBLE GOODS}

In preventing the problems that the economic market for intangible goods confronts with, there comes the EVILA Project- Making full value of good ideas by leveraging intellectual assets for financing SMEs in South East Europe" whose main purpose is facilitating innovation, entrepreneurship and knowledge based economy, facilitating the SMEs' access and of the potential entrepreneurs towards the requested financial resources for the implementation of these actions. The main idea is to contribute to the creation of a unique market for good ideas and innovation in the South Eastern Europe (South East Europe Transnational Cooperation Programme, Application Form, 2012).

The specific objectives of the project are the developing and application of some commune valuation methods for the intangible assets in order to facilitate the financing from the intellectual property rights. The set of methods elaborated and summed during the EVLIA project, from the best case studies and business practices, gives the foundation for standard evaluation method of the intellectual property all over Europe. This would be a crucial step for accomplishing the European Commission's purpose to create the framework conditions 
for facilitating the appearance of a Unique Market of Intellectual Property. It is important to mention that this project tried to promote the cohesion and the equilibrium of the weak structural points of the regions that are less developed by the transfer of knowledge and of top practices of these regions.

During the European research project EVLIA, it was developed an approach on three levels with the purpose of grouping the evaluation approaches as a result of their relevance in what concerns the real current situation of the financial industry and of the supposed capacity of evolving and integrate new approaches in their internal procedures. The three level approach (Figure 2) has ne following structure (Weltz, Fichtinger \& Kerschbaum, 2013).

\begin{tabular}{|c|c|c|}
\hline Level 1 & Level 2 & Level 3 \\
\hline $\begin{array}{l}\text { „Intellectual } \\
\text { property in } \\
\text { restrained sense” }\end{array}$ & $\begin{array}{c}\text { "Intellectual } \\
\text { proprerty in large } \\
\text { sense" }\end{array}$ & „Intangible assets” \\
\hline
\end{tabular}

\section{Figure 2: EVLIA valorification model on 3 levels.}

Level 1 is the basis zone of the registered industrial rights, more specifically, the patents. In this area there are a great number of business cases together with instruments or valuation approaches.

Level 2 is named the middle evaluation zone and it follows the industrial property including the brands and the trademark. Here we have some proofs of transactions and business from the South Eastern Europe, United States and China.

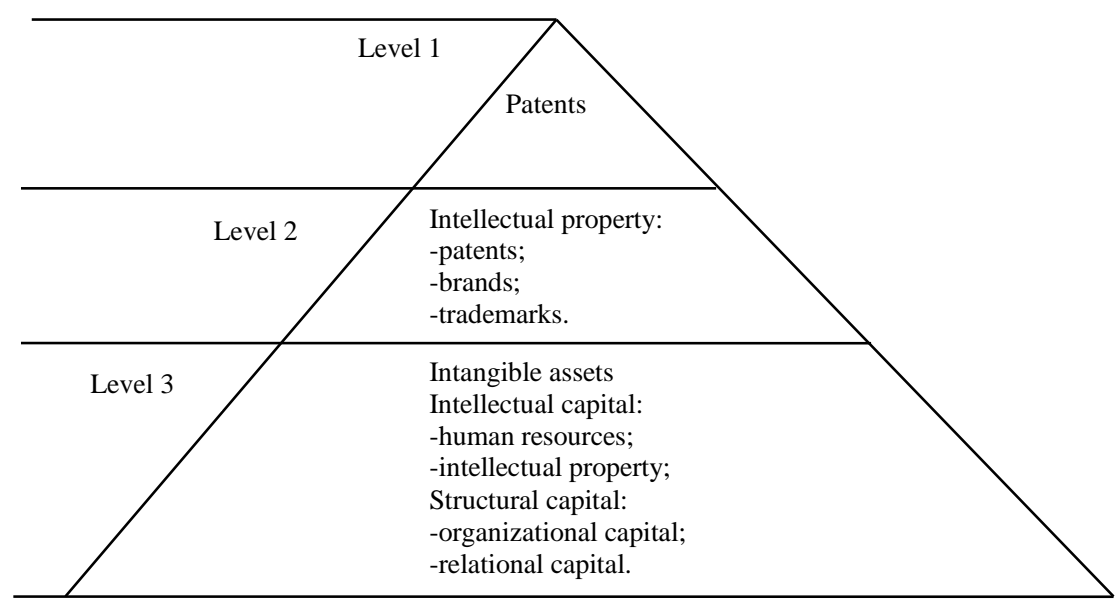

Figure 3: EVLIA valorification model - extended 
Level 3 is the largest area of evaluation that includes all the intangible assets categories, for example: intellectual capital and the structure capital of structure. This level is considered to give a comprehensive image over the organization's value of creation, based on intellectual assets and knowledge. An expanded representation of the EVLIA model is represented in figure no. 3 .

Usually, the banks don't accept and don't implement any instrument of valuation in what concerns the knowledge based organizations. Even so, in what regards the bookkeeping practices and reporting, a number of European organizations and Asian organizations give substantial information about intangible assets to the interested persons.

For example, on behalf of the corporations, Infosys Technologies situated in Bangalore, registered to the market of New York - NYSE, gives the comprehensive divulgation of a great range of intellectual assets. Until now, from behalf of the banks there are no proofs regarding an implemented structural approach in practice.

Levels 1 and 2 reflect the current situation of a valuation and evaluation limited of the categories of intangible assets, individual selected as it shows the business transactions that implies corporations and financial industry of Europe, United States and Asia. For both levels, in practice is suggested valuation methods that would be relevant, based on standards of valuation published in Austria by the Austrian Institute of Standard, developed in partnership with all the relevant parts involved (Weltz, Fichtinger \& Kerschbaum, 2013). Even so, we must understand that the financial experts, most of the times use a completely different set of approaches of practical evaluation. Level 3 is dedicated to the development on medium and long term and to the final purpose of valuation of the intangible assets in business transactions: the approach of the integrated valuation.

The described approaches can be seen as additions for developing a framework for working that is accepted in practice, more advanced, and a set of applied methodologies in the context of business transactions all over Europe. The European research project EVLIA, pretends to bring such a working frame in order to give a model and a plan for a standardized valuation procedure of the intangible assets.

\section{CONCLUSIONS}

The importance of the knowledge based organizations is irrefutable, especially when we talk about a continuous changing economy, where information gives power and innovation is always present, because in order to progress, adapting is not enough, you must innovate, think and act with a step ahead your competitors, but in the interest of the consumers and of the organization. In other words, innovation must be as a basis stone for any entrepreneur's support.

Any entrepreneur or manager must base his strategy on the intangible assets that represent unlimited and renewable resources. This fact gives strength to the idea that sustains that intangible assets have a higher utility than the tangible assets. 
On the competitive markets from these days, the use and protection of these intellectual assets makes the difference between success and failure. Moreover, the intellectual property is an important means in the innovation processes and part of the intangible assets portfolio of an organization. Even so, it hasn't been enough evaluated like most of the assets, and treated right as a true asset in bookkeeping by the experts of the financial market. At the European level and also international level is still missing a general standard valuation approach. In the nowadays practice of the investment specialists, the traditional methods (the income approach, the comparison of market approach or the costs approach) are applied in combination with additional information of the market according to the specific circumstances.

Following, the organizations must manage the most correct possible the intangible assets for identifying additional modalities for valuing them. This subject has been approach by the EVLIA project that has as a main purpose the elaboration, the testing and transmitting a methodology that supports the creation of a unique market for innovation, in private the evaluation of the intellectual assets and of the intangible assets in the South Eastern Europe. The making of an unique market would mean a great progress for the European market and also for the global one taking into consideration the opportunities that result from this process.

What should be taking into view by the entrepreneurs and investors is to see beyond what they already know, beyond the static data or the prognostics of the markets. It is important that each of these categories to be aware of the role that they have in the context of the development of the economy and of the organizations based on knowledge. In the very moment when the awareness passes from individual to the collectivity we could talk about change to the level of mentalities and this will lead to the evolution of the collectivity and of the economy altogether.

\section{REFERENCES}

Manus, J. P. (2012). Intellectual Property: From Creation to Commercialisation - A Practical Guide for Innovators \& Researchers (ed. First). Cork, Ireland: OAK TREE PRESS.

Oprean, C., Țîțu, M., Bucur, V. (2011). Managementul global al organizaţiei bazată pe cunoştinţe. București, Romania: AGIR.

South East Europe Transnational Cooperation Programme (2012), Application Form. Document reg. no.: INTRA-5182931- Documentaţie Proiect european de cercetare EVLIA.

Weltz, A. G., Fichtinger, M., \& Kerschbaum, F. (2013). Analiza de Status Quo pentru valorificarea proprietăţii intelectuale în zona Europei de Sud Est şi în context Global. Viena: Institutul "Economica" de Cercetare Economică. 